Article

\title{
Euroregions and Local and Regional Development-Local Perceptions of Cross-Border Cooperation and Euroregions Based on the Euroregion Beskydy
}

\author{
Honorata Howaniec ${ }^{1, *}$ and Marcin Lis ${ }^{2}$ (D) \\ 1 Department of Marketing and Entrepreneurship, University of Bielsko-Biala, Willowa 2, \\ 43-309 Bielsko-Biala, Poland \\ 2 Faculty of Applied Sciences, WSB University in Dabrowa Górnicza, Zygmunta Cieplaka 1c, \\ 41-300 Dąbrowa Górnicza, Poland; mlis@wsb.edu.pl \\ * Correspondence: hhowaniec@ath.bielsko.pl
}

Received: 21 July 2020; Accepted: 21 September 2020; Published: 22 September 2020 updates

\begin{abstract}
The cross-border regions, which are the peripheral regions, are struggling with $\mathrm{m}$ troubles. They often include high unemployment, insufficiently developed infrastructure, or inadequate language skills of residents, which are barriers to exploiting the potential of such regions. One kind of remedy is the assumption of the European Union's regional policy, under which Euroregions are created. These units, constituting a form of cooperation between the regions of the European Union member states, candidate countries, and the regions of their neighbors, with the support of local and regional authorities, constitute support for the competitiveness and development of border areas. The purpose of this study is to verify how people perceive the activity and effectiveness of Euroregions, as well as to try to determine whether they think Euroregions contribute to local and regional development. In this research, an online and self-administered survey was used, with two parts: one related to Euroregions in general, and the other to a specific, selected Euroregion. Despite the fact that the Polish experience has not been as long as in other parts of Europe, the results show that the Euroregions are positively evaluated by people, and they rate them as important for development of the regions.
\end{abstract}

Keywords: cross-border cooperation $(\mathrm{CBC})$; Euroregions; local and regional development; Euroregion Beskydy

\section{Introduction}

All economies evolve and develop over time, and there have been many theories developed that have tried to explain this. For the local and regional development of border regions, one of significance is cross-border cooperation (CBC). It is not important if this cooperation is within the Euroregions, but the solutions of the European Union have not only made this cooperation easier, but in contemporary times, the Euroregions mean exactly CBC. The border regions, treated as less important and peripheral, have got a new opportunity. The Euroregions allow them to animate cooperation in every important field for the region. Bottom-up policies have caused local entities and society to be more significant for the regions, which should be more interested in local and regional development. Thus, planned cross-border cooperation should contribute to the development and growth of the region. The $\mathrm{CBC}$ plays an important role in this process [1,2].

However, there is also criticism of European $\mathrm{CBC}$ policy implementation in the literature. The perceived problems are related to the low involvement of the local community and not taking it 
into account in the actions that are undertaken by the Euroregions [3,4]. Inhabitants of border regions very often do not know the activities undertaken by Euroregions, nor do they participate in making decisions regarding border areas. However, amid optimism about growing cooperation, there is a diffuse debate about how $\mathrm{CBC}$ should be developed [5].

According to the authors, increasing the involvement of residents in the region's problems will increase their willingness to cooperate and reduce the sense of alienation from decision-making processes concerning the region. Listed reasons were the basis for examining how people perceive the activity and effectiveness of Euroregions based on the Euroregion in which they live and/or work, and whether in their opinion the actions taken by this Euroregion contribute to the development of the region.

\section{The Role of Cross-Border Cooperation and the Euroregions in the Process of Local and Regional Development}

\subsection{Local and Regional Development-Models and Factors}

Socio-economic development is the cause of much research. The first work to question why growth rates vary by nation or region was Smith's (1776) "Inquiry into the nature and causes of the wealth of nations". However, this publication did not trigger a series of studies immediately. We can find work by classical economists such as Smith, Malthus (1798), and Ricardo (1817), which dealt with temporal and spatial differences in living standards, and Marx's (1867) alternative interpretation of the driving forces in long-term capitalist accumulation, but further major theorizing did not occur until the 20th century [6]. Academic works in this area caused an appearance of such terms as: "First", "Second", and "Third World"; "developed" and "less developed countries"; "high", "middle", and "low-income economies"; "transition"; and "emerging" and "post-socialist" economies [7].

Studies on economic convergence are rooted in the neoclassical theory of economic growth. The dominant concept between 1950 and 1980 was the Solow model of exogenous growth, where the output is determined by three factors: capital, labor, and technological progress [8,9]. Technology is assumed to be a public good, while technological progress (including advances in basic science) is assumed to be exogenous. This means that technological progress has the same contribution to economic growth in all regions, leading to the assumption that GDP per capita should grow at the same rate in all regions [10]. Nevertheless, due to the different regional initial conditions and, accordingly, to the different regional capital-labor ratios, poorer regions (with a low capital-labor ratio) are growing faster than the richer ones; thus, regional inequalities tend to decrease and, finally, should disappear. The model of interregional convergence offers a simple explanation for the evolution of regional inequalities: assuming constant returns on capital, when a region reaches equilibrium as a result of long-term development, it will grow at the rate of technological progress. The further a region is from stable, the higher GDP per capita growth may be. Consequently, poor regions should grow faster than richer ones, which may result in income convergence (Solow, Swan, Heckscher, Ohlin, and Samuelson) $[8,11,12]$. However, the spatial dimension of modern regional growth theory can be traced to several sources. The location theorists provide a framework for understanding the role of transportation costs in regional growth and decline: Weber (1929), Hoover (1937), Greenhut (1956), and Isard (1956). Although location theory alone does not provide a theory of regional development, the transport cost models have had a strong influence on later theories of economic growth and development. External benefit theory, which began with Marshall $(1890,1961)$, has also had a huge significance to regional development. According to Marshal and Hoover (1937), industries may cluster together for reasons unrelated to internal cost considerations; moreover, the external benefits tend to increase with the number and output of collocating firms [6].

An attempt to combine some of these perspectives into a more general theory of the spatial location of firms can be found in the works of Christaller (1933) and Losch (1954), a theory of central places. The basis of Christaller's theory was the idea of functional interdependence between the city and the surrounding rural area. The author, guided by the basic assumption that "the chief profession, 
or chief characteristic, of a town is to be the center of a region", created a completely new framework for the study of the geography of settlement. The basic idea developed by Losch was that the relative size of a company's market area, defined as the territory in which it sells its product, is determined by the combined effects of economies of scale and transportation costs. The central place theory developed by both authors was the base of numerous studies of the spacing of cities, the size and number of cities, the relationships between the population sizes and functional complexity of urban places, and the patterns of consumer shopping behavior, and for many researchers provides a framework for regional planning [13].

Another very influential theory was the export base model developed in the 1950s by Tiebout (1956a, 1956b) and North $(1956,1955)$. According to North (1955) the regional growth in local political, economic, and social institutions is largely determined by the region's response to exogenous world demand. Tiebout, meanwhile, was pointing to instances when exports are not the sole determinant of regional economic growth, and he argued for the "stages" theory of economic growth. However, in an early discussion on the merits of the export-base theory, Tiebout stated he finally agreed with North that the necessary condition for regional economic growth was the creation of an export base [14-17].

Another approach to regional growth is represented by the neoclassical growth theory, which, in contrast to the demand-side approach of export base theory, uses supply-side models of investment in regional productive capacity: Perloff et al. (1960), Borts and Stein (1964), Williamson (1965), and Barro and Sala-i-Martin (1999) [18-21]. The neoclassical growth models assumed, however, the convergence, which even in its weaker formulation as long-run constant per capita income growth rates, or conditional convergence, has come under attack from many sides. According to Perroux "space as force" exists, which as a type of network that is held together by centripetal forces has formed the basis of most growth pole theories. In Perroux's (1950) original formulation, a growth pole referred to linkages between firms ("propulsive firms" and other) and industries [22]. Similarly argues Hirschman (1958) [23]. However, Boudeville (1966) was placing Perroux's formulation into geographic space [6]. Myrdal (1957) argues that underdeveloped regions can benefit from growth in developed regions through the "spread" effects of diffusing innovation into the "lagging" region and growing export markets for products from less developed regions. However, these benefits will usually be compensated for by the "backwash" effects of capital and labor flows from a less developed region to a developed region. According to this theory, the results of free trade between regions only serve to strengthen this cumulative causation process by further catalyzing growth in developed regions at the expense of less developed regions [24].

Another point of view of regional economic development is presented by structuralist theories. Representatives of this trend see economic growth as a path-dependent evolution at various stages of economic maturity: Schumpeter (1934), Perloff et al. (1960), Hoover and Fisher (1949), Rostow $(1977,1956)$, Thompson (1968), and Henderson (1968) [18,25-29]. For example, Hoover and Fisher (1949) present that in the early stages of regional growth, agricultural production predominates, and the economy is largely self-sufficient, but an improvement of transportation makes producers begin to specialize and engage in outside trade with other regions. As the production profits of the region's primary mining and agricultural industries decline, the region enters the industrialization phase. At the most advanced stage, the region specializes in export production. One of the more widely accepted theories was also Rostow's linear stages of growth model, modified from Marx's stages theory of development [27]. According to this model, the economic growth and development is possible with advantageous accumulation of capital, which means domestic savings and foreign investment. The Rostow model postulated that an economy goes through five stages of development: the traditional society, the preconditions for take-off, the take-off, the drive to maturity, and the age of high mass-consumption [30]. The Rostow linear stages were questioned, similarly to others [31]. Endogenous growth theories emerged: Schumpeter (1947), Cass (1965), Koopmans (1965), and Richardson (1973), [32-35], which have only recently begun to consider the role of space and geography in shaping patterns of regional growth and decline, such as Nijkamp and Poot (1998) [36]. 
Were noticed that capital accumulation is not a sufficient condition for the development of countries, regions, and society. It is very important factor, but also important are cultural, political, social, institutional, and geographical factors, which create the right conditions for development [7]. Porter, for example, proposed a different approach: a linear stage model emphasizing a nation's type of development drivers as a source of competitive advantage [37]. Porter (1990) postulated that a factor-driven economy gains its competitive advantage from natural resources, favorable conditions for growing crops, and low cost labor sources; an investment-driven economy gains it from the willingness of firms and individuals to invest in modern plants, equipment, and technologies; an innovation-driven economy gains it based on firms creating novel processes, products, and business models; and a wealth-driven economy (also one in decline) is one where investment is based on accumulated capital in low risk ventures and activities like shopping centers [27].

The problem of local and regional development was also the subject of studies of such authors as, among others: Prebisch [38], Frank [39], and Harvey [40] (general problems of development of regions/countries and its disproportions), Blakely and Bradshaw [41], Fitzgerald and Green Leigh [42], Stimson and Stough [43], and Pike et al. [44] (local and regional development of localities and regions in the historically industrialized and urbanized countries of the Global North), and Bebbington [45] and Cypher and Dietz [46] (industrialization and urbanization of nations in the Global South). All models and theories try to explain how the economies develop.

Very significant to the theory and practice of local and regional development was some kind of exhaustion of traditional "top-down" policy approaches from national centers that has proved too rigid and inflexible to cope with diverse regional and local circumstances $[47,48]$. A rejection of the "top-down" policy paradigm of local and regional development caused "bottom-up" policies to be considered proper in a contemporary time. Local entities have been authorized to achieve growth. They were entrusted with responsibility for local and regional development [47].

The entities of local development now are the authorities and units from economic and social environment that represent the local society. The effect of their activities is the process of creating new values at the local or regional level, as new companies, jobs, new goods, and services that meet local and supra-local demand, as well as the so-called hard factors such as real estate, infrastructure facilities, and a high-quality natural environment. Also very important to local development are soft and intangible factors such as knowledge, qualifications, and new skills of the local community [49,50].

Bottom-up Local Economic Development (LED) policies have been adopted in developed and developing countries with little questioning of their theoretical justifications/foundations and little understanding of the factors conditioning their success. In practice, it means that the traditional top-down policy apparatus, grounded in solid macro and micro economic theories, has been complemented (or even replaced) by a new policy approach whose theoretical foundations remain, at best, implicit [47]. That is why it is necessary to fill this conceptual void and deliver a conceptual framework for the diagnosis of local conditions and for the identification of the most appropriate remedies and the ex-post assessment of their impact [47].

\subsection{The Objectives of the Euroregions and Cross-Border Cooperation}

The special areas where we are interested in local and regional development are Euroregions, which we can understand as a territorial units formed by two or more contiguous sub-national units belonging to at least two separate states [51], with common or similar historical, cultural, and often economic attributes [52]. The partners maintain autonomy, and their goal is to jointly implement long-term strategies that are beneficial for the entire region. Euroregions are one of the forms of cross-border cooperation ( $\mathrm{CBC}$ ), and the main cause of their existence is an attempt to re-inscribe border areas formerly considered marginal and peripheral to the territorial projects of nation-states to those of centrality and dynamism at the very heart of Europe [53,54]. Cooperation in Euroregions, including a territorial partnerships, changes the functioning of not only the cooperating organizations, but also their surroundings, as well as the region in which they operate. The changes are especially valuable 
when the goals of the cooperating organizations are a part of the broadly understood objectives of cross-border cooperation. In this case, they have a decisive impact on building the socio-economic cohesion of the Euroregion, in accordance with the interests of the area in which it is located [55-57].

The first studies of borders and border regions were in the beginning of the 20th century, and since then they have been continued [1]. Experiences related to Euroregions also have existed for a relatively long time: the first initiative was the EUREGIO, founded on the Dutch-German border in 1958 [51]. However, the most significant impact on the development of the cross-border partnerships in Europe was European integration and the support of cross-border cooperation.

The Euroregions and cross-border cooperation are widely discussed in the literature. From the Polish perspective, we have the widely discussed cooperation on the Polish-German border: Stryjakiewicz (1998) [58], Guz-Vetter (2002) [59], Ciok (2004) [60], Ciok and Raczyk (2008) [61], Dołzbłasz (2012) [62], Raczyk, Dołzbłasz and Leśniak-Johann (2012) [63], Szmigiel-Rawska and Dołzbłasz (2012) [64], Dołzbłasz and Raczyk (2016) [65], Wróblewski (2010, 2014, 2017) [66-68] and also Krätke (1999) [69], Grix and Knowles (2002) [70], Brym (2011) [71], and Mirwaldt (2012) [72]. CBC in the Polish-Czech border area is also widely discussed, for example: Vaishar et al. (2013) [73], Skorupska (2014) [74], Dołzbłasz (2016) [75], Kurowska-Pysz (2016) [56], and Böhm and Opioła (2019) [76]. Many studies are also devoted to Polish-Ukrainian cooperation, including Koszyk-Białobrzeska and Kisiel (2003) [77], Miszczuk (2007) [78], Shcherba (2008) [79], and Jakubowski et al. (2017) [57]. However, a little less attention is paid to Polish-Russian CBC (Kawałko (2008) [80] and Zieliński (2012) [81]), Polish-Lithuanian CBC (Poleszczuk et al. (2013) [82]), and Polish-Slovak CBC (Howaniec and Kurowska-Pysz (2014) [55] and Kurowska-Pysz and Greblikaite (2017) [83]). For some researchers, it is interesting as a global phenomenon across borders all over the world, for others, it is interesting to examine the results of the CBC practices of European border regions. Their role was noticed especially in studies on region-building [84,85]. However, these questions remain relatively underdeveloped in the border studies literature [86]. The vast majority of researchers consider the practical aspects of $\mathrm{CBC}$ of the regions close to them.

Euroregions can be characterized as a more or less institutionalized collaboration between contiguous subnational authorities across national borders [51]. Organizationally, Euroregions usually have a council, a presidency, subject matter oriented working groups, and a common secretariat. The term Euroregion can thus refer both to a territorial unit and to organizational entities, usually identified with the secretariat. Legally, the cooperation can take different forms, ranging from legally non-binding arrangements to public law bodies. Most often, the Euroregions are concerned with administrative matters that demand cross-border co-ordination at the local level. Traditionally, such co-ordination concerned spatial planning, transport, and environmental externalities. However, the scope of Euroregional action was lately widened to initiatives in economic policy, the labor market, and social and cultural issues [51]. However, the most important goal of the functioning of Euroregions is animation of territorial cooperation of different types of units in all areas of activity, which can finally contribute to the development of the region. While supranational factors play a crucial role in providing a viable context for $\mathrm{CBC}$ in Europe, the local innovative activities are the engines of regional economic performance; they generate new ideas later translated into economic growth. Unfortunately, the effectiveness of the cross-border cooperation in Euroregions is conditioned by many factors [87], and the scope and dynamics of this cooperation are determined by, i.e., cultural, social, and economic barriers $[50,88]$.

How is CBC defined? According to Art. 2.1 of the 1980 Madrid Convention, cross-border cooperation is defined as: “ . . any concerted action designed to reinforce and foster neighborly relations between territorial communities or authorities within the jurisdiction of two or more Contracting Parties and the conclusion of any agreement and arrangement necessary for this purpose [89]. In operational terms, cross-border cooperation can be defined as any type of concerted action between public and/or private institutions of the border regions of two (or more) states, driven by geographical, economic, cultural/identity, political/leadership factors, with the objective of reinforcing the (good) neighborhood 
relations, solving common problems, or managing jointly resources between communities through any cooperation mechanisms available" [90].

There are three types of $\mathrm{CBC}$ :

1. Awareness raising cooperation, i.e., cross-border "relations of good neighborliness". It is the type of cross-border cooperation that requires the least political commitment. In practice, this very often means regular bilateral visits or town twinning arrangements to promote cultural and commercial ties.

2. Mutual aid cooperation, which may take place on an ad hoc basis, required only in the event of an emergency, but may also constitute a formal standing arrangement for risk cooperation or crisis management on a continuous basis between adjacent public authorities.

3. Functional cooperation, that is, longer lasting, requiring more resources, and greater involvement of neighboring local/regional political and administrative authorities. These cooperation projects aim to solve problems, create business opportunities, promote cultural exchange, and reduce invisible barriers to worker mobility.

4. Common management of public resources/services. This type of CBC goes beyond the implementation of EU regional funds and seeks common strategies for the reorganization and rationalization of state services, benefits, and other public funded provisions in function of border regions [90].

$\mathrm{CBC}$ is conducted at various levels. It all depends on the degree of political commitment to CBC development, the amount of resources involved, and the results or externalities for the local economy and population. Despite these differences and the many conditions of the $\mathrm{CBC}$, this cooperation plays an important role in the process of integrating of border regions.

\section{Objectives and Methodology}

The conditions of functioning of Euroregions are not the same for all. As we noticed, the different historical, cultural, and often economic factors determine the $\mathrm{CBC}$ and their results. However, the implementation of Euroregions and $\mathrm{CBC}$ has been associated with a bottom-up approach under the European Integration and Cohesion Policy, which means among other things that Euroregions involve both local and regional governments in undertaking the most important issues for the regions. The goal is for the Euroregions to become integral actors in cross-border activity and to provide a bottom-up structure for addressing cross-border issues under the auspices of the EU [5]. Meanwhile, the vision of $\mathrm{CBC}$ programs may not necessarily be shared by the target population. The gap between the projected goals of the European institutions that oversee the Euroregions and the reality experienced by the people living in border regions is noticed. Unfortunately, such claims confirm a lack of concern about local people and other key actors in the border regions. As Houtum and Strüver emphasize, the local people sometimes are not aware that they live in a border region managed through a Euroregion, or they are not interested in the idea of $\mathrm{CBC}$ [3]. There are voices that have called for changes in the approach to CBC [4,91].

The main goal of the study is to identify the activity of Euroregions and their perception by local society. The problem of perception of activity and effectiveness of Euroregions is very important, not only because of the European integration process, but also due to the development of the region and local society. The European CBC is treated as a cumulative process that comprehends various stages and border regions, and it contributes to development of the so-called Euroregions or Working Communities [92-94]. However, the condition for the success of the whole process is an increase of involvement of the local society.

The Euroregion Beskydy, chosen for this research, was created in 2000, on the basis of the "Beskydy without borders" agreement, which was an initiative of the local authorities of the Beskydy municipalities on the Polish-Slovak-Czech border. The Euregion Beskydy is small-scale cross-border region. In total, the Euroregion Beskydy covers a range of about $6343 \mathrm{~km}^{2}$, including Poland: 
$3288 \mathrm{~km}^{2}$, Slovakia: $2083 \mathrm{~km}^{2}$, and the Czech Republic: $972 \mathrm{~km}^{2}$. This area is inhabited by nearly 1,385,036 inhabitants (Poles: 843536; Slovaks: 295500, Czechs: 246000) [95]. On the Polish side, the Euroregion Beskydy covers the poviats Bielsko, Pszczyna, Żywiec (Silesian Voivodeship), Oświęcim, and Suski (Lesser Poland Voivodship). The largest city in the Euroregion on the Polish side is Bielsko-Biała. The Euroregion Beskydy is located in the immediate vicinity of such Euroregions as Silesia, Cieszyn Silesia, and the Tatra Mountains.

According to the adopted vision, the Euroregion Beskydy should to be a "place that develops thanks to cross-border cooperation of local government units, organizations, and people operating in all areas of social life. Thanks to this, its inhabitants can benefit from the advantages and potential of the border area conditioned by geographical location" [96]. The main strategic goals of the Euroregion are:

- the exchange of experience and information on the development of the region and the labor market,

- spatial planning and construction,

- solving common problems in the field of transport, communication, communications, and telecommunications,

- solving common problems regarding ecology and the natural environment,

- solving common problems concerning economy, trade, industry, and small and medium enterprises,

- solving common problems related to agriculture, forestry, and the food industry,

- tourism development, tourism taking into account its improvement in the border area,

- undertaking cooperation in the field of education, youth exchange and sport, and education,

- supporting activities for cultural exchange and protection of the common cultural heritage,

- supporting activities related to the prevention and removal of the effects of natural disasters, as well as care for the security of citizens and mutual cooperation of rescue services within the Euroregion.

In the Euroregion Beskydy, many projects and micro-projects have been carried out over almost 20 years of activity. These were projects covering economic development, cultural exchange, local democracy, environmental protection, tourism, and health, all implemented in cooperation with the Polish, Czech, or Slovak side [97]. This Euroregion was chosen by the authors of this study due to its physical proximity. Both authors are connected with this region.

The main purpose of this study is to verify how people who are connected with the Euroregion (living, working, or studying in the region) perceive and rate the Euroregions and Euroregion Beskydy, as well as to try to determine whether they think Euroregions contribute to the local and regional development.

Three research hypotheses were adopted in this study, according to which it is assumed that:

Hypothesis 1 (H1). The functioning of Euroregions is assessed positively from the perspective of the inhabitants of border regions.

Hypothesis 2 (H2). The functioning of the Euroregion Beskydy is positively evaluated by the inhabitants of the Euroregion Beskydy and surrounding poviats.

Hypothesis 3 (H3). The functioning of the Euroregion in the perception of the inhabitants has contributed to the development of the region, improvement of cross-border cooperation, and the increase of the region's competitiveness.

In order to verify the adopted hypotheses, a survey was conducted on a group of 400 inhabitants of poviats belonging to the Euroregion Beskydy and neighboring poviats (Poland side of Euroregion Beskydy), through targeted choice (persons who live in Euroregion Beskydy, while maintaining the representativeness of the sample in terms of gender and age) and the Internet. In the group there 
were also people associated with the Euroregion Beskydy, who work or study in the E and know the Euroregion Beskydy, but don't live there. Due to the immediate vicinity of other Euroregions, it was assumed that the respondents also had an opinion about other Euroregions.

The study consisted of two parts: the first (general) related to the Euroregions in general, and the second, directly related to the Beskydy Euroregion.

The study was conducted using the PAPI (Paper and Pen Personal Interview) and CAWI (Computer Assisted Web Interview) technique. The survey was prepared in Polish. Online surveys were available at: https://ankieta.interaktywnie.com/, and information about the surveys was sent by mail and shared on Facebook. Basic information about the research is presented in Table 1.

Table 1. Basic information about the research.

\begin{tabular}{cc}
\hline Specification & Research \\
\hline Research method & Survey \\
\hline Research technique & $\begin{array}{c}\text { PAPI (paper and pen personal interview) } \\
\text { CAWI (computer-assisted web interview) }\end{array}$ \\
\hline Research tool & $\begin{array}{c}\text { Paper questionnaire } \\
\text { Electronic questionnaire }\end{array}$ \\
\hline Sample selection & $\begin{array}{c}\text { Targeted } \\
\text { Sample size }\end{array}$ \\
& $\begin{array}{c}\text { Surveys distributed: } 400 \text { in total (without online surveys) } \\
(0.029 \% \text { of the total population of Euroregion Beskydy; } \\
0.047 \% \text { of Polish side of Euroregion Beskydy) } \\
\text { Surveys for calculations: 220 }\end{array}$ \\
& $\begin{array}{c}\text { (0.016\% of the total population of Euroregion Beskydy; } \\
0.026 \% \text { of Polish side of Euroregion Beskydy) }\end{array}$ \\
\hline Spatial extent of research & $\begin{array}{c}\text { Poviats: Bielsko, Pszczyna, Żywiec (Silesian Voivodeship) } \\
\text { Oświęcim, Suski (Lesser Poland Voivodship) }\end{array}$ \\
\hline Research date & June 2019-June 2020 \\
\hline
\end{tabular}

Data source: collected by this research.

Apart from the online survey, we distributed 400 questionnaires. After rejection of invalid responses, 220 questionnaires were the basis for the calculation (151 physical survey forms, 69 on-line surveys). Rate of return was very low, and a lot of surveys were incomplete. In the opinion of the authors, the study was difficult for surveying, because a lot of people are not interested in Euroregions and local development. The sample characteristic is presented in Table 2. The analyses of data were carried out using a qualitative approach. In the questions about barriers in border regions that negatively affect cross-border cooperation, the types of obstacles developed in the European Commission study titled "The overcoming obstacles in border regions. Summary of results of internet social consultations" were used [98].

Table 2. The sample characteristic (\%).

\begin{tabular}{ccccc}
\hline & Gender & Female & \multicolumn{2}{c}{ Male } \\
\hline & $\mathbf{( \% )}$ & & 50 & \multicolumn{2}{c}{50} \\
\hline Age & Under 25 years & From 26 to 40 years & From 41 to 55 years & Over 56 years \\
\hline $\mathbf{( \% )}$ & 32 & 27 & 37 & 4 \\
\hline Education & $\begin{array}{c}\text { Primary/Middle } \\
\text { school }\end{array}$ & Vocational school & $\begin{array}{c}\text { High school } \\
\text { education }\end{array}$ & $\begin{array}{c}\text { A university } \\
\text { degree }\end{array}$ \\
\hline (\%) & 0 & 2 & 22 & 76 \\
\hline Place of residence & Village & $\begin{array}{c}\text { City under } \mathbf{5 0 , 0 0 0} \\
\text { residents }\end{array}$ & $\begin{array}{c}\text { A city from } \mathbf{5 0} \text { to } \\
\mathbf{1 0 0 , 0 0 0} \text { residents }\end{array}$ & $\begin{array}{c}\text { A city of over } \\
\mathbf{1 0 0 , 0 0 0} \text { residents }\end{array}$ \\
\hline (\%) & 35 & 18 & 12 & 35 \\
\hline
\end{tabular}

Data source: own empirical research. 


\section{Results}

\subsection{The Way of Perception of Euroregions}

The majority of responders know the concept of Euroregions. Among answerers, 83\% said that they recognized this concept. For the respondents, the Euroregion is above all a form of cooperation between regions of the Member States of the European Union, candidate countries, and regions of their neighbors (55\% of indications), but also just a separate European region, located on the border of two or more neighboring countries (50\%). A minority said that it is an organization established to coordinate cooperation in an area located on the border of two or more neighboring countries by the parties to the Euroregional Agreement and approved by the European Union, which financially support its activities (37\%) and a unit, the creation and development of which involved representatives of local and regional self-government authorities (27\%) (Figure 1).

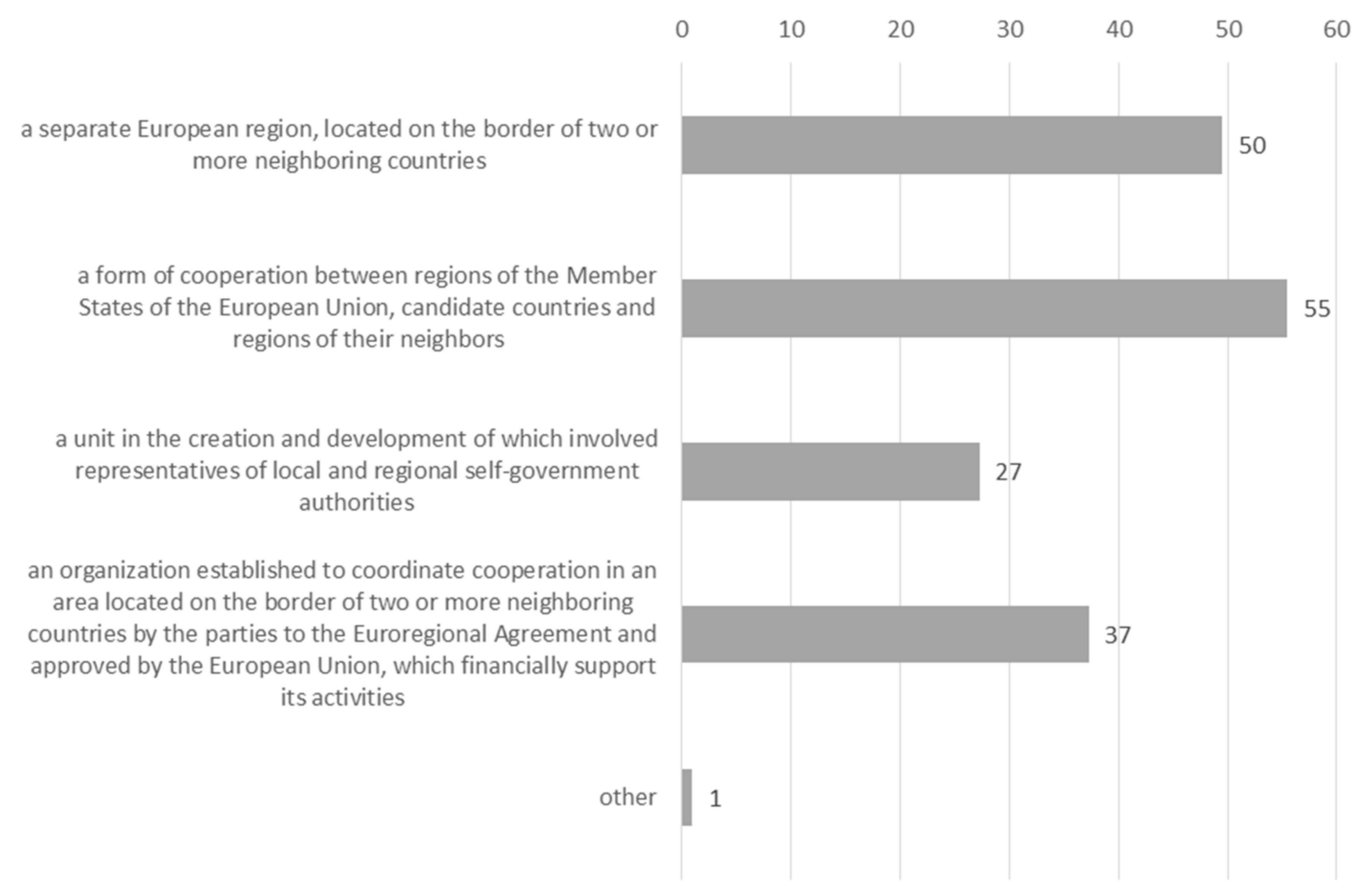

Figure 1. The way of defining the term Euroregion by the respondents (the respondents could choose more than one answer-) in \%.

According to respondents, the main goals that Euroregions should achieve are strengthening economic and socio-cultural conditions (75\% indications), building and consolidating mutual ties between regions and entities operating in them (69\%), and removing economic and infrastructural obstacles and inequalities (56\%). Almost one third of answerers think that the objective is facilitating the implementation of European spatial development policy (36\%) and making decentralized regions a driving force for cross-border cooperation (33\%). Fewer believe that it is formulating principles for building the foundations of mutual trust and cooperation between European institutions and their effectiveness (29\%) and defining methods of solving problems, manifestations of underdevelopment, and nuisance characteristics of peripheral areas $(24 \%)$. The lowest number of people indicated that this goal is changing the nature of borders and overcoming state regulations regarding the impenetrability of borders (22\%) (Figure 2). 


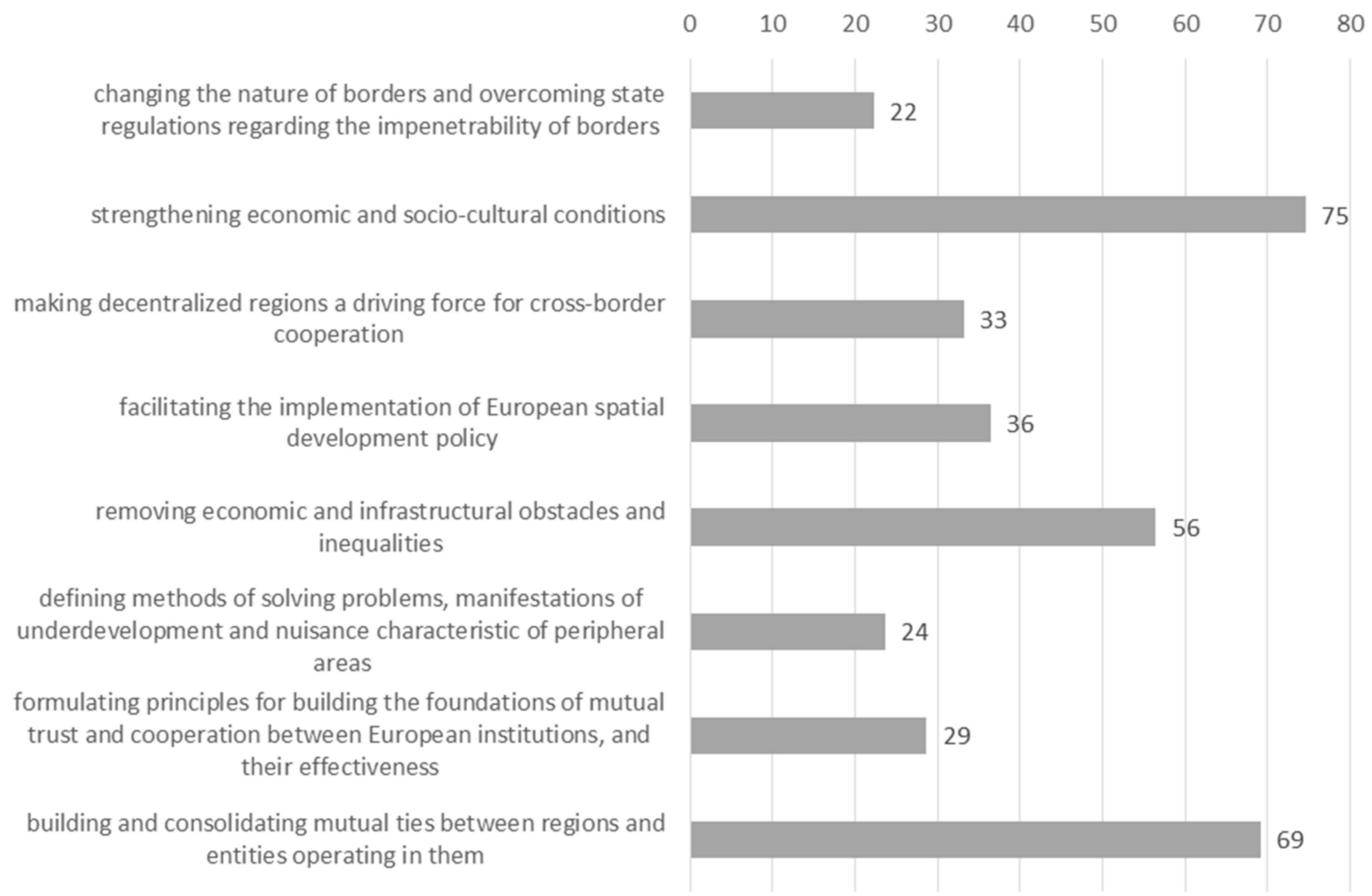

Figure 2. The objectives of Euroregions according to the respondents (the respondents could choose more than one answer) in \%.

The vast majority of respondents assess the functioning of Euroregions positively: $16 \%$ very positively and $47 \%$ rather positively. A relatively large group (35\%) evaluate it neutrally. This group said that they do not rate it either positively or negatively. However, most importantly, only $1 \%$ assess Euroregions negatively, and nobody said they were definitely negative (Figure 3).

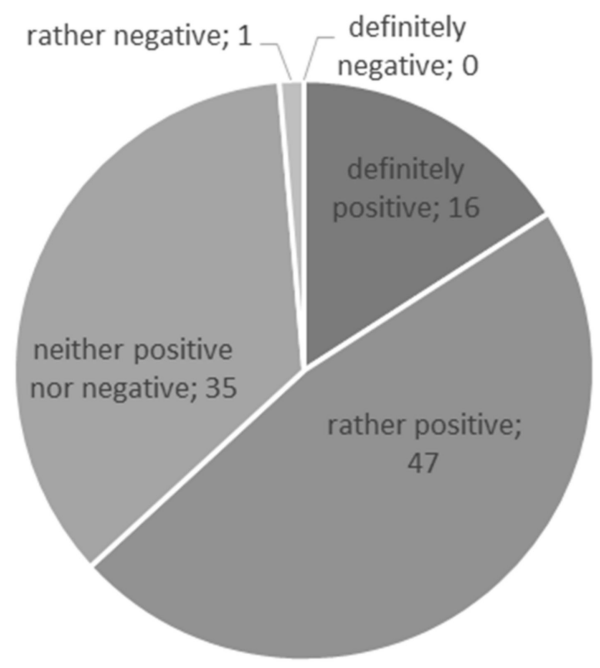

Figure 3. A general rating of the functioning of the Euroregions (\%).

Therefore, as we can see, the Euroregions are assessed positively, and people expect a lot from this cooperation. The most important point for responders is that $\mathrm{CBC}$ can reinforce the economic and socio-cultural environment of regions and that it builds and consolidates the mutual ties between regions and entities operating in them. A relatively significant point is also the possibility of removing economic and infrastructural obstacles and inequalities in regions. 
The most important obstacles that we can notice in the development of border regions according the surveyed are legal and administrative barriers $(60 \%)$, degree of public authorities' interest in foreign cooperation ( $41 \%$ ) and language barriers $(40 \%)$. Relatively fewer answerers think that such barriers are an economic differences (34\%), citing other obstacles such as a lack of access to information, a lack of a common framework for cooperation, access to data or media $(28 \%)$ and social and cultural differences $(25 \%)$. Interesting is that for a few people this kind of obstacle is the lack of trust (19\%) (Figure 4).

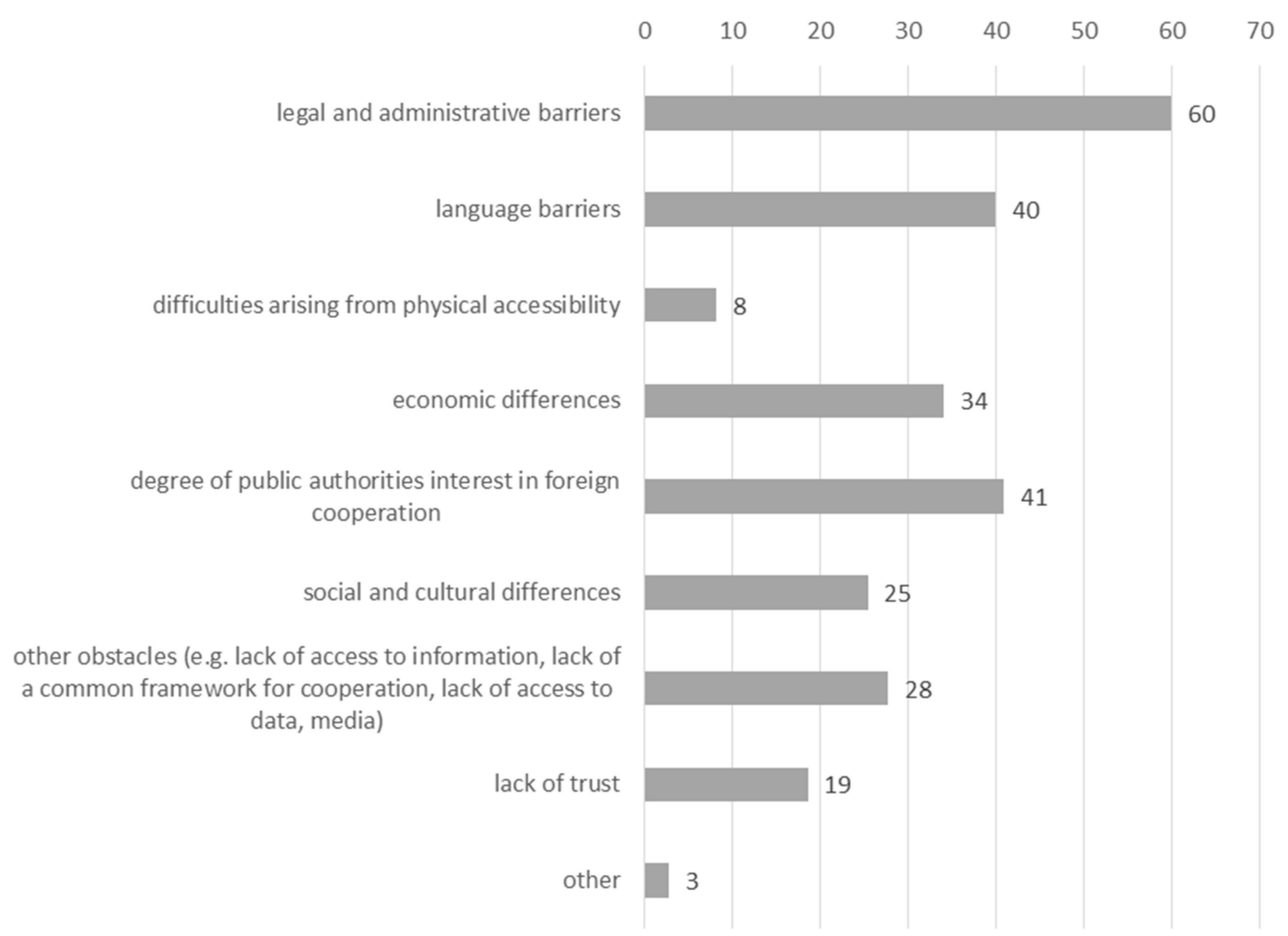

Figure 4. The obstacles in the development of border regions according to the respondents (the respondents could choose more than one answer) in \%.

\subsection{Evaluation of the Euroregion Beskydy}

For the question "how do you rate the situation in the Euroregion Beskydy?", most respondents said that it is very good. They rate especially highly the level of public security ( $41 \%$ both rates: rather high and very high) and the condition of the natural environment (37\%). It is some kind of confirmation of the way this region is perceived in Poland and elsewhere. The Beskydy Region is famous as a winter holiday resort and is well-known for natural, attractive areas with mountains and forests. In opinion of answerers, also very high are the level of development of economic infrastructure (36\%), the transport availability (35\%), the level of development of social infrastructure (34\%), and economic development (also 34\%). Less responders think that the advantage of the region is quantity and quality of labor resources $(29 \%)$ and the region's activity towards investors $(28 \%)$. The labor costs have the least indicators (only $17 \%$ ) (Table 3).

The speed of development of the Beskydy Region in the last 10 years (compared to the previous period) is positively evaluated too. For $14 \%$ of respondents, the Beskydy Region is definitely developing faster than before. About 54\% think that it is developing rather faster than before. Unfortunately, $29 \%$ also think that this growth is neither faster nor slower. However, only $2 \%$ thinks that the Beskydy Region is developing rather slower than previously, and nobody thinks that this development is definitely slower than before (Figure 5). 
Table 3. The rating of Euroregion Beskydy by the respondents (\%).

\begin{tabular}{|c|c|c|c|c|c|c|}
\hline The Area of Rating & $\begin{array}{l}\text { Very } \\
\text { Low }\end{array}$ & $\begin{array}{l}\text { Rather } \\
\text { Low }\end{array}$ & Middle & $\begin{array}{l}\text { Rather } \\
\text { High }\end{array}$ & $\begin{array}{l}\text { Very } \\
\text { High }\end{array}$ & $\begin{array}{l}\text { I Have No } \\
\text { Opinion }\end{array}$ \\
\hline transport availability & 2 & 12 & 27 & 32 & 3 & 23 \\
\hline $\begin{array}{c}\text { quantity and quality of } \\
\text { labor resources }\end{array}$ & 3 & 14 & 28 & 23 & 6 & 26 \\
\hline labor costs & 0 & 12 & 35 & 13 & 5 & 35 \\
\hline market absorption & 0 & 7 & 32 & 25 & 5 & 30 \\
\hline $\begin{array}{l}\text { level of development of } \\
\text { economic infrastructure }\end{array}$ & 1 & 9 & 31 & 31 & 5 & 22 \\
\hline $\begin{array}{l}\text { level of development of } \\
\text { social infrastructure }\end{array}$ & 0 & 7 & 32 & 30 & 4 & 26 \\
\hline $\begin{array}{l}\text { level of economic } \\
\text { development }\end{array}$ & 0 & 10 & 33 & 28 & 6 & 23 \\
\hline $\begin{array}{c}\text { condition of the natural } \\
\text { environment }\end{array}$ & 2 & 17 & 22 & 24 & 13 & 21 \\
\hline level of public security & 0 & 7 & 25 & 30 & 11 & 25 \\
\hline $\begin{array}{c}\text { region's activity towards } \\
\text { investors }\end{array}$ & 1 & 8 & 31 & 20 & 8 & 31 \\
\hline
\end{tabular}

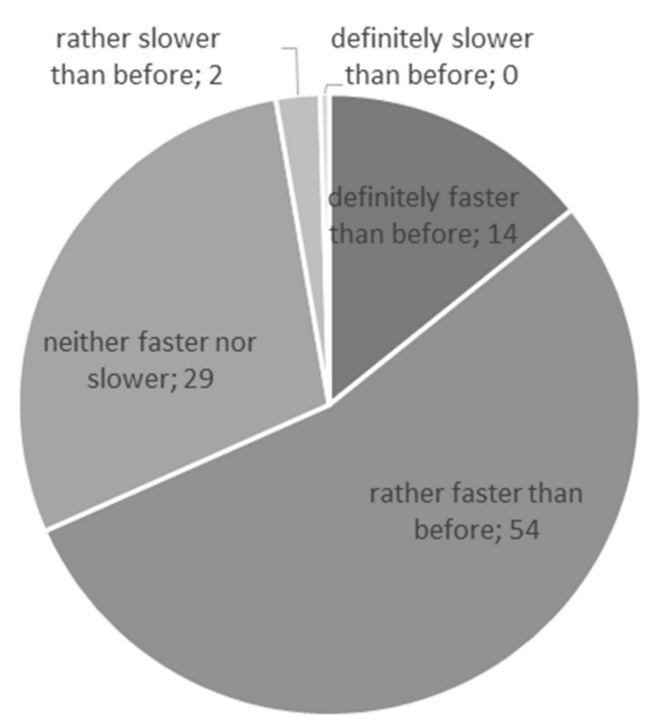

Figure 5. The speed of development of the Beskydy Region in the last 10 years (compared to the previous period) in \%.

Moreover, the respondents link the development of the Beskydy Region with the functioning of the Beskydy Euroregion. For the vast majority, the Euroregion Beskydy has a contribution to the upward growth of the Beskydy region, perhaps this influence in their opinion is not very large, but they rate this positively. For example, the answerers positively rate the impact of the functioning of the Euroregion Beskydy to the region in areas such as the level of development of social infrastructure (36\% both rates: rather high and very high), the level of economic development $(36 \%)$, the level of public security (34\%), the level of development of economic infrastructure $(34 \%)$, and in each area and the availability of transport (also 34\%). The other indicators' grades are not too low either. However, many of those surveyed answer that the impact of the Euroregion's structure and CBC on the region is in the middle, or that they have no idea how to rate it (Table 4). 
Table 4. The rating of the impact of Euroregion Beskydy on the Beskydy Region (\%).

\begin{tabular}{|c|c|c|c|c|c|c|}
\hline The Area of Rating & $\begin{array}{l}\text { Very } \\
\text { Low }\end{array}$ & $\begin{array}{l}\text { Rather } \\
\text { Low }\end{array}$ & Middle & $\begin{array}{l}\text { Rather } \\
\text { High }\end{array}$ & $\begin{array}{l}\text { Very } \\
\text { High }\end{array}$ & $\begin{array}{c}\text { I Have No } \\
\text { Opinion }\end{array}$ \\
\hline transport availability & 1 & 8 & 27 & 28 & 5 & 30 \\
\hline $\begin{array}{l}\text { quantity and quality of } \\
\text { labor resources }\end{array}$ & 0 & 10 & 26 & 20 & 6 & 37 \\
\hline labor costs & 3 & 12 & 27 & 14 & 2 & 42 \\
\hline market absorption & 0 & 9 & 26 & 19 & 5 & 40 \\
\hline $\begin{array}{l}\text { level of development of } \\
\text { economic infrastructure }\end{array}$ & 1 & 7 & 25 & 27 & 7 & 33 \\
\hline $\begin{array}{l}\text { level of development of } \\
\text { social infrastructure }\end{array}$ & 0 & 7 & 25 & 28 & 9 & 31 \\
\hline $\begin{array}{c}\text { level of economic } \\
\text { development }\end{array}$ & 0 & 7 & 25 & 28 & 9 & 31 \\
\hline $\begin{array}{c}\text { condition of the natural } \\
\text { environment }\end{array}$ & 4 & 10 & 29 & 19 & 7 & 32 \\
\hline level of public security & 1 & 8 & 26 & 26 & 8 & 31 \\
\hline $\begin{array}{c}\text { region's activity towards } \\
\text { investors }\end{array}$ & 0 & 5 & 26 & 24 & 7 & 38 \\
\hline
\end{tabular}

The respondents also positively rate the cross-border cooperation within the Beskydy Euroregion. Many of them believe that the $\mathrm{CBC}$ has improved in the region during the last 10 years. For $9 \%$, this improvement is categorical, but $44 \%$ said that this cooperation is just better than previously. The significant proportion ( $40 \%$ ) answered that they have no idea how to rate its level, but only $6 \%$ rate $\mathrm{CBC}$ as worse than previously (Figure 6).

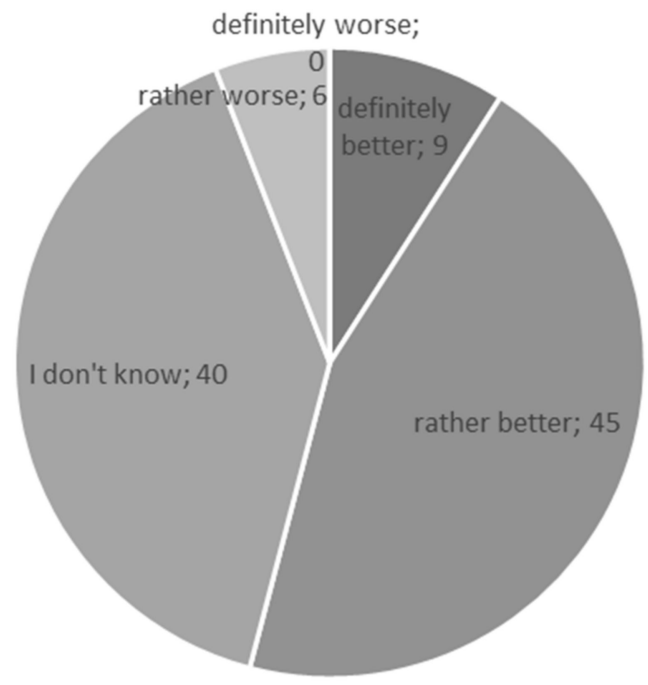

Figure 6. Perception of $\mathrm{CBC}$ in the Euroregion Beskydy in the last 10 years (\%).

The surveyed notice almost the same barriers in the development of Euroregion Beskydy as in the border regions, but with the difference that less people indicate these obstacles. The most important for them are the legal and administrative barriers (38\%), the economic differences $(28 \%)$, and the degree of interest of public authorities in foreign cooperation (28\%). In fourth place are language barriers $(24 \%)$. Other areas have less than a one fourth of indicators (Figure 7). 


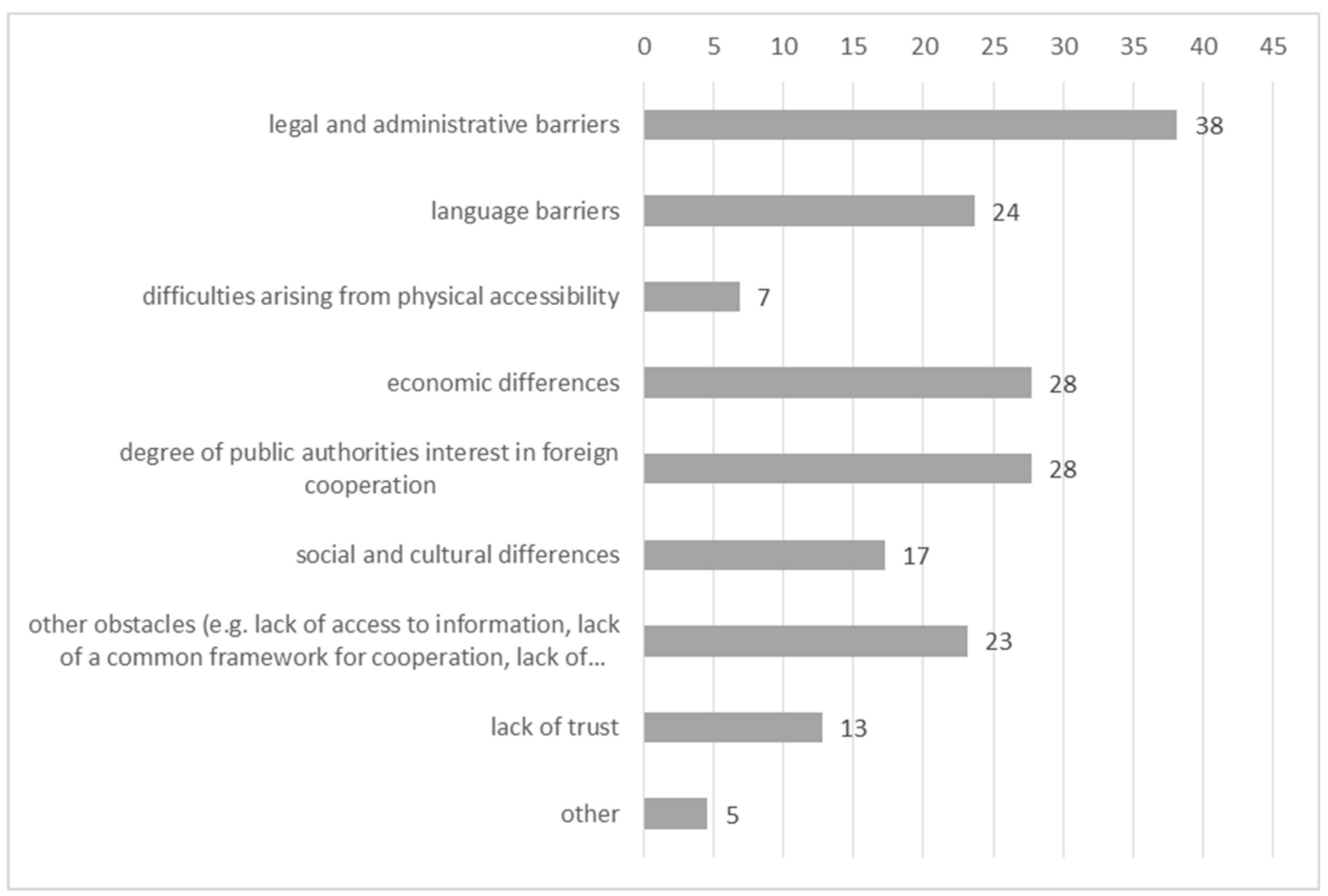

Figure 7. The obstacles in the development of Euroregion Beskydy according to the respondents (the respondents could choose more than one answer) in \%.

However, opinions are divided when it comes to the use of region's potential by Euroregion Beskydy. Almost $46 \%$ rate this positively, but only $6 \%$ say that Euroregion Beskydy definitely uses the potential of region. The vast majority $(40 \%)$ gave the answer "rather yes", which means that they do not grade this process as perfect. A significant proportion also say that they have no idea how to rate it $(38 \%)$. A relatively small proportion of answerers said that they think that the Euroregion does not use the region's potential properly (14\%) (Figure 8$)$.

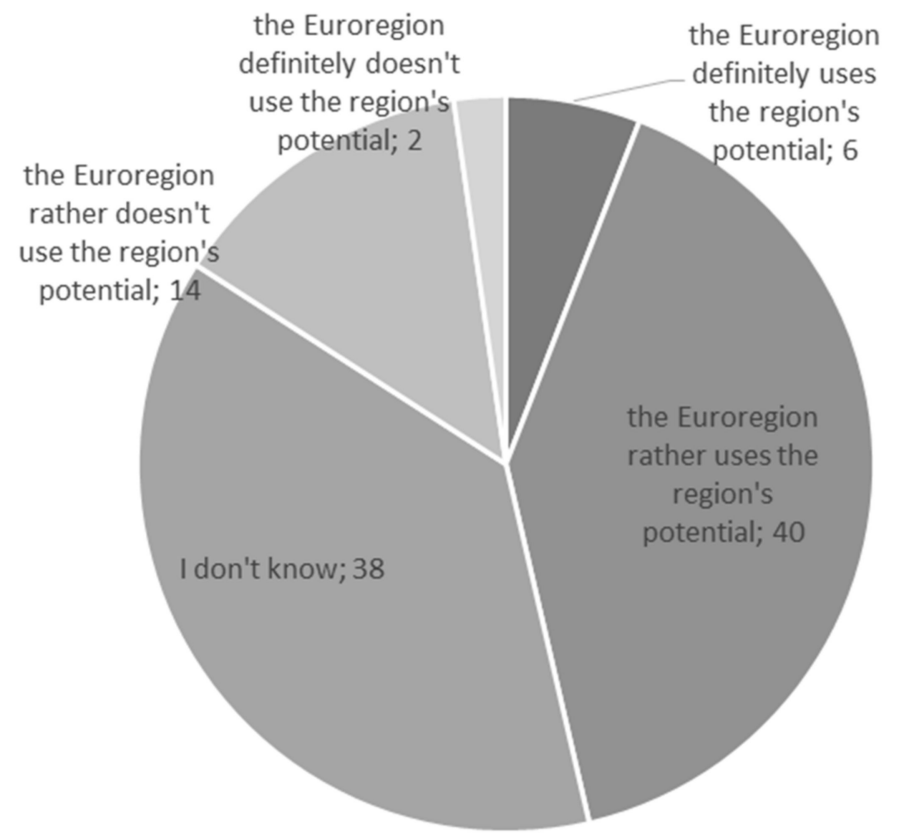

Figure 8. Perception of the use of the region's potential by the Euroregion Beskydy. 
The vast majority, in spite of it all, think that the establishment of the Euroregion Beskydy has had a positive impact on the development of the Beskydy Region: 19\% rate this very positively, and $53 \%$ say that it is rather positive. A relatively big propotion have no opinion. Only $2 \%$ say that the Euroregion Beskydy has no influence on the increase of the region. Unfortunately, solely $14 \%$ of respondents know the initiatives that have been taken by Euroregion Beskydy, which confirms a weak knowledge and interest of local society in this.

The surveyed relatively positively evaluate the involvement of local authorities and business in support of the Euroregion Beskydy developments. About one third of them rate that these entities should rather be taking part in support of the Euroregion. The vast majority evaluate this neutrally (Table 5).

Table 5. An involvement of local authorities and business in support of the Euroregion Beskydy development $(\%)$.

\begin{tabular}{cccccc}
\hline Entity & $\begin{array}{c}\text { Definitely } \\
\text { Positive }\end{array}$ & $\begin{array}{c}\text { Rather } \\
\text { Positive }\end{array}$ & $\begin{array}{c}\text { Neither } \\
\text { Positive Nor } \\
\text { Negative }\end{array}$ & $\begin{array}{c}\text { Rather } \\
\text { Negative }\end{array}$ & $\begin{array}{c}\text { Definitely } \\
\text { Negative }\end{array}$ \\
\hline local authorities & 5 & 31 & 58 & 5 & 0 \\
\hline business & 5 & 34 & 57 & 3 & 0 \\
\hline
\end{tabular}

The respondents also believe that the Euroregion Beskydy has a positive impact on the competitiveness of the region. Over half of respondents notice that the Euroregion Beskydy has an effect on Beskydy Region's development, but only 13\% said that the Euroregion has a strong influence on the competitiveness of the region. One third said that they cannot rate this, but only $4 \%$ answered that Euroregion has rather little influence on the competitiveness of the region (Figure 9).

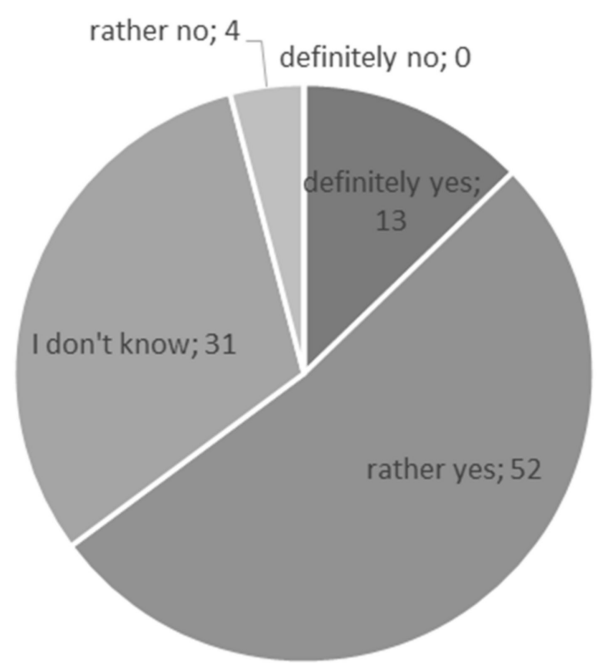

Figure 9. Assessment of the impact of the Beskydy Euroregion on the competitiveness of the region.

\section{Discussion}

A significant proportion of respondents know the concept of Euroregions and assess them positively. In the case of the surveyed, Euroregions are primarily associated with $\mathrm{CBC}$, which indirectly confirms that Euroregions are properly fulfilling their goals, and one could really put an equal sign between the concept of Euroregion and CBC [6]. Emphasizing that Euroregions are organizations set up to coordinate cooperation in the cross-border area is less popular.

Such a point of view is hidden also in the responses about the main goals of Euroregions. For the respondents, the most important thing is that Euroregions support economic and socio-cultural conditions (consistent with cohesion policy) and $\mathrm{CBC}$, but this is not about linking between regions 
but about actual cooperation between other entities that operate in this region. It is also important to involve Euroregions in removing economic and infrastructural obstacles and inequalities in regions.

The emphasis on the removing of obstacles by Euroregions means that people see their occurrence. Unfortunately, in their opinion, the main ones are the legal and administrative barriers. This means that respondents do not consider the process of $\mathrm{CBC}$ to be easy and secure and describe the applicable rules and requirements as relatively difficult. The respondents also indicated the degree of public authorities' interest in foreign cooperation as a barrier. Such an answer may result from an insufficiently high assessment of previous activities undertaken by public authorities in the field of CBC. An additional perceived barrier are language differences. However, other studies also point to the significant, negative impact of language barriers on CBC [99].

The Polish, Czech, and Slovak border region has considerable economic potential and similar economic structures, but at the same time a number of development problems. The opportunity for the region is its touristic character (mountain tourism, winter sports). Also important for the region are a large number of monuments, numerous national and landscape parks, and the high natural value of the region. According to Dołzbłasz and Raczyk, all of this means that there is greater potential for integration in this region. However, it may be connected with the creation and consolidation of a "cooperation monoculture" dominated by tourist-oriented activities [100].

In 2013, i.e., in the previous programming period, activity on the Polish-Czech and Polish-Slovak border was not rated very highly. Although the clear dominance of micro-projects in the type structure on the Polish-Czech and Polish-Slovak border was typical for the Micro-Projects Fund (various types of events), the share of activities related to environmental protection (despite all the natural values of the borderland), development of human resources, or activities supporting entrepreneurship was assessed as very low. Compared to the Polish-German border, the Polish southern border was characterized by a much larger share of tourist projects. They included mainly 'meetings' (a large number of cultural, sporting, and tourist events were an opportunity to meet residents of the Polish-Czech and Polish-Slovak border) and joint cross-border promotional and marketing activities [101].

At present, the situation in the Euroregion Beskydy is well assessed by residents and people who know the region relatively well. The highest rated aspects were the level of public safety and the state of the environment. The level of economic development, the level of social infrastructure development, and the level of economic infrastructure development were also assessed as high.

These results overlap with the results of other studies. Bielsko-Biala, which is the largest city of the Euroregion Beskydy on the Polish side (over 170,000 inhabitants), took first place in the environment area in the Ranking of Polish Sustainable Cities and sixth place in the whole ranking (Bielsko-Biala obtained a result of $66.31 \%$, while the best city in the ranking, Warsaw, obtained $67.74 \%$ ) [102]. A 6th place in the ranking was also taken by Bielsko-Biala also in the Ranking of 100 functional areas in 2018 [103]. They rated not only environmental protection, but also economics, society, quality of life, and other factors.

For respondents, barriers to $\mathrm{CBC}$ in the Euroregion Beskydy are similar to those they perceive as obstacles to the development of cross-border regions. These are legal and administrative barriers, economic differences, and the degree of interest of public authorities in foreign cooperation. Surprisingly, respondents did not indicate other obstacles, such as lack of access to information, lack of a common framework of cooperation, or lack of access to data and media as the most important for CBC. Meanwhile, obstacles such as "lack of information" were considered to be the main limitation of cooperation in the regions along the Franco-Spanish border [104]. The respondents also relatively positively assessed the involvement of local authorities and business in supporting the development of the Euroregion Beskydy.

According to the respondents, the region's development is definitely faster than before or rather faster than before. They see the positive impact of the Euroregion on the region in such areas as development of social infrastructure, level of economic development, level of public security, level of development of economic infrastructure, and transport availability. The respondents also positively 
assess cross-border cooperation in the Euroregion Beskydy. Many of them believe that $\mathrm{CBC}$ has improved over the last 10 years. Although respondents are not convinced that the Euroregion uses the potential of the region, they believe that the Euroregion Beskydy has a positive impact on its development. Respondents also believe that the Euroregion Beskydy has a positive impact on the competitiveness of the region. Unfortunately, very few of the answerers knew the initiatives taken by the Euroregion.

Referring to the hypotheses, they have all been confirmed. Despite numerous problems related to the functioning of Euroregions, respondents assess them positively (H1). The Euroregion Beskydy is also positively assessed. Although research confirms the strong focus of this Euroregion on tourism-related activities, and only a few people know the initiatives taken by the Euroregion, the Euroregion Beskydy is functioning well in their opinion (H2). Furthermore, respondents combine the Euroregion's activities with the development and growth of the region (H3). The most important goal of the functioning of Euroregions is to animate territorial cooperation of various types of units in all areas of activity, and this goal is well implemented by the Euroregion Beskydy.

Due to the small number of respondents (low rate of return and interest in participating in the survey), these surveys can be the basis for conclusions accepted by the deduction. A broader view of the problem could take place if the research were also carried out on the Czech and Slovak side.

Author Contributions: Conceptualization, H.H. and M.L.; Data curation, H.H.; Formal analysis, H.H. and M.L.; Funding acquisition, M.L.; Investigation, H.H. and M.L.; Methodology, H.H. and M.L.; Resources, H.H. and M.L.; Supervision, H.H. and M.L.; Validation, H.H. and M.L.; Visualization, M.L.; Writing-original draft, H.H. and M.L.; Writing-review \& editing, H.H. and M.L. All authors have read and agreed to the published version of the manuscript.

Funding: The project is funded under the statutory research undertaken by both Universities (University of Bielsko-Biala and WSB University in Dabrowa Górnicza).

Conflicts of Interest: The authors declare no conflict of interest.

\section{References}

1. Guo, R. Cross-Border Resource Management. Theory and Practice, 3rd ed.; Elsevier: Amsterdam, The Netherlands, 2017; p. 203.

2. Cappellano, F.; Rizzo, A. Economic drivers in cross-border regional innovation systems. Reg. Stud. Reg. Sci. 2019, 6, 460-468. [CrossRef]

3. Houtum, H.; Strüver, A. Border, strangers, doors and bridges. Space Polity 2002, 6, 141-146. [CrossRef]

4. Hospers, G.J. Borders, bridges and branding: The transformation of the Öresund region into an imagined space. Eur. Plan. Stud. 2006, 14, 1015-1033. [CrossRef]

5. González-Gómez, T.; Gualda, E. Reporting a bottom-up political process: Local perceptions of cross-border cooperation in the southern Portugal-Spain region. Eur. Urban Reg. Stud. 2014, 23, 1-13. [CrossRef]

6. Dawkins, C.J. Regional Development Theory: Conceptual Foundations, Classic Works, and Recent Developments. J. Plan. Lit. 2003, 18, 131-172. [CrossRef]

7. Pike, A.; Rodríguez-Pose, A.; Tomaney, J. Local and regional development in the Global North and South. Prog. Dev. Stud. 2014, 14, 12-30. [CrossRef]

8. Solow, R.M. A contribution to the theory of economic growth. Q. J. Econ. 1956, 70, 65-94. [CrossRef]

9. Durlauf, S.N.; Kourtellos, A.; Minkin, A. The local Solow growth model. Eur. Econ. Rev. 2001, 45, 928-940. [CrossRef]

10. Fagerberg, J. Convergence or divergence? The impact of technology on "Why Growth Rates Differ". J. Evol. Econ. 1995, 5, 269-284. [CrossRef]

11. Swan, T.W. Economic growth and capital accumulation. Econ. Rec. 1956, 32, 334-361. [CrossRef]

12. Mankiw, N.G.; Romer, D.; Weil, D.N. A contribution to the empirics of economic growth. Q. J. Econ. 1992, 107, 407-437. [CrossRef]

13. King, L.J. Central Place Theory. Web Book of Regional Science; Grant, I.T., Ed.; Regional Research Institute, West Virginia University: Morgantown, WV, USA, 1985; pp. 19-30.

14. Tiebout, C.M. Exports and regional economic growth. J. Political Econ. 1956, 64, 160-164. [CrossRef] 
15. Tiebout, C.M. Exports and regional economic growth: Rejoinder. J. Political Econ. 1956, 64, 169. [CrossRef]

16. North, D.C. Exports and regional economic growth: A reply. J. Political Econ. 1956, 64, 165-168. [CrossRef]

17. North, D.C. Location theory and regional economic growth. J. Political Econ. 1955, 63, 243-258. [CrossRef]

18. Perloff, H.S.; Edgar, S.D., Jr.; Eric, E.L.; Richard, F.M. Regions, Resources and Economic Growth; Johns Hopkins University Press: Baltimore, MD, USA, 1960.

19. Borts, G.; Stein, J. Economic Growth in a Free Market; Columbia University Press: New York, NY, USA, 1964.

20. Williamson, J.G. Regional inequality and the process of national development: Adescription of the patterns. Econ. Dev. Cult. Chang. 1965, 13, 158-200. [CrossRef]

21. Barro, R.J.; Sala-i-Martin, X. Economic Growth; MIT Press: Cambridge, MA, USA, 1999.

22. Perroux, F. Economic space: Theory and applications. Q. J. Econ. 1950, 64, 89-104. [CrossRef]

23. Hirschman, A.O. The Strategy for Economic Development; Yale University Press: New Haven, CT, USA, 1958.

24. Meardon, S.J. Modeling agglomeration and dispersion in city and country: Gunnar Myrdal, Francois Perroux, and the New Economic Geography. Am. J. Econ. Sociol. 2001, 60, 25-57. [CrossRef]

25. Schumpeter, J. The Theory of Economic Development; Harvard University Press: Cambridge, MA, USA, 1934.

26. Hoover, E.M.; Fisher, J.L. Research in regional economic growth. In Problems in the Study of Economic Growth; Universities-National Bureau Committee on Economic Research, Ed.; National Bureau of Economic Research: New York, NY, USA, 1949; pp. 173-250.

27. Hunter, M. The stages of economic development from an opportunity perspective: Rostow extended. Geopolitics Hist. Int. Relat. 2012, 2, 52-80.

28. Thompson, W.R. A Preface to Urban Economics; Johns Hopkins University Press: Baltimore, MD, USA, 1968.

29. Henderson, J.V. The sizes and types of cities. Am. Econ. Rev. 1974, 64, 640-656.

30. Rostow, W.W. The Stages of Economic Growth: A Non-Communist Manifesto (1960). In The Globalization and Development Reader: Perspectives on Development and Global Change, 2nd ed.; Roberts, J.T., Hite, A.B., Chorev, N., Eds.; Wiley-Blackwell: Hoboken, NJ, USA, 2014; pp. 52-61.

31. McMichael, P. Development and Social Change: A Global Perspective, 6th ed.; Sage Publications, Inc.: Thousand Oaks, CA, USA, 1996; p. 424.

32. Schumpeter, J. Capitalism, Socialism, and Democracy; Harper: New York, NY, USA, 1947.

33. Cass, D. Optimum growth in an aggregative model of capital accumulation. Rev. Econ. Stud. 1965, 32, $233-240$. [CrossRef]

34. Koopmans, T.C. On the Concept of Optimal Economic Growth; Cowles Foundation Discussion Papers 163; Cowles Foundation for Research in Economics, Yale University: New Haven, CT, USA, 1963.

35. Richardson, H.W. Regional Growth Theory; Macmillan: London, UK, 1973.

36. Nijkamp, P.; Poot, J. Spatial perspectives on new theories of economic growth. Ann. Reg. Sci. 1998, 32, 7-37. [CrossRef]

37. Porter, M.E. The Competitive Advantage of Nations; Free Press: New York, NY, USA, 1990.

38. Prebisch, R. The Economic Development of Latin America and Its Principal Problems; Department of Economic Affairs: New York, NY, USA, 1950; p. 59.

39. Frank, G.A. Dependent Accumulation and Underdevelopment; Palgrave Macmillan: London, UK, 1978; p. 226.

40. Harvey, D. Spaces of Global Capitalism Towards the Theory of Uneven Geographical Development; Verso: London, UK; New York, NY, USA, 2006.

41. Blakely, E.; Bradshaw, T. Planning Local Economic Development: Theory and Practice, 3rd ed.; Sage Publications, Inc.: Thousand Oaks, CA, USA, 2002.

42. Fitzgerald, J.; Green Leigh, N. Economic Revitalization: Cases and Strategies for City and Suburb, 5th ed.; Sage Publications, Inc.: Thousand Oaks, CA, USA, 2013.

43. Stimson, R.; Stough, R.R. Regional economic development methods and analysis: Linking theory to practice. In Theories of Local Economic Development: Linking Theory to Practice; Rowe, J.E., Ed.; Ashgate: Farnham, UK, 2008; pp. 169-192.

44. Pike, A.; Rodríguez-Pose, A.; Tomaney, J. What kind of local and regional development and for whom? Reg. Stud. 2007, 41, 1253-1269. [CrossRef]

45. Bebbington, A. Global networks and local developments: Agendas for development geography. J. Econ. Soc. Geogr. 2003, 94, 297-309. [CrossRef]

46. Cypher, J.M.; Dietz, J.L. The Process of Economic Development, 4th ed.; Routledge: New York, NY, USA, 2014. 
47. Crescenzi, R.; Rodríguez-Pose, A. Reconciling top-down and bottom-up development policies. Environ. Plan. A 2011, 43, 773-780. [CrossRef]

48. Pike, A.; Rodríguez-Pose, A.; Tomaney, J. Local and Regional Development, 1st ed.; Routledge: London, UK, 2006; p. 328.

49. Markowski, T. Zarządzanie Rozwojem Miast; PWN: Warsaw, Poland, 1999.

50. Howaniec, H. Znaczenie kształtowania wizerunku miejsca docelowego w rozwoju lokalnym na przykładzie "Beskidzkiej 5". In Teoria i Praktyka Rozwoju Lokalnego i Regionalnego; Barcik, R., Biesok, G., Eds.; Wydawnictwo Naukowe ATH: Bielsko-Biała, Poland, 2009; pp. 135-145.

51. Perkmann, M. Euroregions: Institutional Entrepreneurship in the European Union. In Globalization, Regionalization and Cross-Border Regions; Perkmann, M., Sum, N.-L., Eds.; Palgrave Macmillan: London, UK, 2002; pp. 103-124.

52. Malinovský, J.; Sucháček, J. Velký Anglicko-Český Slovník Regionálního Rozvoje a Regionální Politiky EU; VŠB-Technical University: Ostrava, Czech Republic, 2006; p. 956.

53. Kramsch, O.T.; Hooper, B. Cross-Border Governance in the European Union, 1st ed.; Routledge: London, UK, 2004; p. 256.

54. Durà, A.; Camonita, F.; Berzi, M.; Noferini, A. Euroregions, Excellence and Innovation across EU borders. A Catalogue of Good Practices; Department of Geography, UAB: Barcelona, Spain, 2018; p. 254.

55. Howaniec, H.; Kurowska-Pysz, J. Klaster Jako Instrument Rozwoju Polsko-Słowackiej Wspótpracy Transgranicznej; Wydawnictwo Naukowe Wyższej Szkoły Biznesu w Dąbrowie Górniczej: Dą̧browa Górnicza, Poland, 2014.

56. Kurowska-Pysz, J. Opportunities for cross-border entrepreneurship development in a cluster model exemplified by the Polish-Czech border region. Sustainability 2016, 8, 230. [CrossRef]

57. Jakubowski, A.; Miszczuk, A.; Kawałko, B.; Komornicki, T.; Szul, R. The EU's New Borderland: Cross-Border Relations and Regional Development; Taylor \& Francis: Abingdon, UK, 2016.

58. Stryjakiewicz, T. The changing role of border zones in the transforming economies of East-Central Europe: The case of Poland. GeoJournal 1998, 44, 203-213. [CrossRef]

59. Guz-Vetter, M. Polsko-niemieckie pogranicze. Szanse i Zagrożenia w Perspektywie Przystapienia Polski do Unii Europejskiej; Instytut Spraw Publicznych: Warszawa, Poland, 2002.

60. Ciok, S. Pogranicze Polsko-Niemieckie. Problemy Wspótpracy Transgranicznej; Wydawnictwo Uniwersytetu Wrocławskiego: Wrocław, Poland, 2004.

61. Ciok, S.; Raczyk, A. Implementation of the EU Community Initiative INTERREG III A at the Polish-German border an attempt at evaluation. In Cross-Border Governance and Sustainable Spatial Development; Central and Eastern European Development Studies; Leibenath, M., Korcelli-Olejniczak, E., Knippschild, R., Eds.; Springer: Berlin/Heidelberg, Germany, 2008.

62. Dołzbłasz, S. Transborder relations between territorial units in the Polish-German borderland. Geogr. Pol. 2012, 85, 23-36. [CrossRef]

63. Raczyk, A.; Dołzbłasz, S.; Leśniak-Johann, M. Relacje Wspótpracy i Konkurencji na Pograniczu Polsko-Niemieckim; Wydawnictwo Gaskor: Wrocław, Poland, 2012.

64. Szmigiel-Rawska, K.; Dołzbłasz, S. Trwałość Wspótpracy Przygranicznej; CeDeWu: Warszawa, Poland, 2012.

65. Dołzbłasz, S.; Raczyk, A. Transborder co-operation and competition among firms in the Polish-German borderland. Tijdschr. Voor Econ. Soc. Geogr. 2016, 108, 141-156. [CrossRef]

66. Wróblewski, Ł.D. Polsko-niemiecko-szwedzka współpraca regionalna w latach 2007-2013 w Euroregionie Pomerania. Przeglad Zach. 2010, 3, 192-200.

67. Wróblewski, Ł.D. Transgraniczne powiązania przedsiębiorstw z Frankfurtu nad Odrą i Słubic, Görlitz i Zgorzelca oraz Guben i Gubina. In Wspótczesne Wyzwania Polityki Regionalnej i Gospodarki Przestrzennej; Ciok, S., Dołzbłasz, S., Eds.; Instytut Geografii i Rozwoju Regionalnego Uniwersytetu Wrocławskiego: Wrocław, Poland, 2014.

68. Wróblewski, Ł.D. Koncepcja Pięciostopniowej Integracji Regionów Przygranicznych; Difin: Warszawa, Poland, 2017.

69. Krätke, S. Regional Integration or Fragmentation? The German-Polish Border Region in a New Europe. Reg. Stud. 1999, 33, 632-642. [CrossRef]

70. Grix, J.; Knowles, V. The Euroregion and the maximization of social capital: Pro Europa Viadrina. Reg. Fed. Stud. 2002, 12, 154-176. [CrossRef] 
71. Brym, M. The enduring importance of national identity in cooperative European Union Borderlands: Polish university students' perceptions on cross-border cooperation in the Pomerania euro-region. Natl. Identities 2011, 13, 305-323. [CrossRef]

72. Mirwaldt, K. The Small Projects Fund and Social Capital Formation in the Polish-German Border Region: An Initial Appraisal. Reg. Stud. 2012, 46, 259-272. [CrossRef]

73. Vaishar, A.; Dvořák, P.; Hubačíková, V.; Zapletalová, J. Contemporary development of peripheral parts of the Czech-Polish borderland: Case study of the Javorník area. Geogr. Pol. 2013, 86, 237-254. [CrossRef]

74. Skorupska, A. Współpraca samorządowa na pograniczu polsko-czeskich. PISM Policy Pap. 2014, 17, 1-8.

75. Dołzbłasz, S. Sieć współpracy transgranicznej na pograniczu polsko-czeskim. Studia Reg. Lokalne 2016, 4, 62-78.

76. Böhm, H.; Opioła, W. Czech-Polish Cross-Border (Non) Cooperation in the Field of the Labor Market: Why Does It Seem to Be Un-De-Bordered? Sustainability 2019, 11, 2855. [CrossRef]

77. Koszyk-Białobrzeska, R.; Kisiel, R. Wspótpraca Transgraniczna Wschodnich Regionów POLSKI; Wydawnictwo Uniwersytetu Warmińsko-Mazurskiego: Olsztyn, Poland, 2003.

78. Miszczuk, A. Zewnętrzna Granica Unii Europejskiej-Ukraina. Możliwości Wykorzystania Dla Dynamizacji Procesów Rozwojowych; Ministerstwo Rozwoju Regionalnego: Warszawa, Poland, 2007.

79. Shcherba, H.I. Współczesne problemy transgranicznej współpracy Ukrainy i Polski w świetle badań socjologicznych. In Spójność Społeczno-Ekonomiczna a Modernizacja Regionów Transgranicznych; Woźniak, M.G., Ed.; Wydawnictwo Uniwersytetu Rzeszowskiego: Rzeszów, Poland, 2008.

80. Kawałko, B. Granica Wschodnia Jako Czynnik Ożywienia i Rozwoju Społeczno-Ekonomicznego Regionów Przygranicznych; Ministerstwo Rozwoju Regionalnego: Warszawa, Poland, 2008.

81. Zieliński, M.J. Cross-Border Co-Operation Between the Kaliningrad Oblast and Poland in the Context of Polish-Russian Relations in 2004-2011. Lith. Foreign Policy Rev. 2012, 28, 11-42.

82. Poleszczuk, J.; Sztop-Rutkowska, K.; Porankiewicz-Żukowska, A.; Kiszkiel, Ł.; Klimczuk, A.; Mejsak, R.J. Samorzadowa i Obywatelska Wspótpraca Transgraniczna w Województwie Podlaskim; Fundacja Laboratorium Badań i Działań Społecznych SocLab: Białystok, Poland, 2013.

83. Kurowska-Pysz, J.; Greblikaite, J. The Polish-Slovak cross-border cooperation in the sphere of culture: The case study analysis. Cult. Manag. Sci. Educ. 2017, 1, 1. [CrossRef]

84. Keating, M. The invention of regions: Political restructuring and territorial government in Western Europe. Environ. Plan. C Gov. Policy 1997, 15, 383-398. [CrossRef]

85. Allen, J.R.; Cochrane, A. Beyond the territorial fix: Regional assemblages, politics and power. Reg. Stud. 2007, 41, 1161-1175. [CrossRef]

86. Scott, J.W. Bordering, Border Politics and Cross-Border Cooperation in Europe. In Neighbourhood Policy and the Construction of the European External Borders; Celata, F., Coletti, R., Eds.; Springer: Cham, Switzerland, 2015; pp. 27-44.

87. Scott, J.W. European politics of borders, border symbolism and cross-border cooperation. In A Companion to Border Studies; Wilson, T.M., Donnan, H., Eds.; Wiley-Blackwell: Hoboken, NJ, USA, 2016; pp. 83-99.

88. Bufon, M. Spatial and Social (Re)Integration of Border and Multicultural Regions: Creating Unity in Diversity? In The New European Frontiers: Social and Spatial (Re)Integration Issues in Multicultural and Border Regions; Bufon, M., Minghi, J., Paasi, A., Eds.; Cambridge Scholars Publishing: Cambridge, UK, 2014; pp. 2-23.

89. European Outline Convention on Transfrontier Co-Operation between Territorial Communities or Authorities, Madrid, 21.V.1980, European Treaty Series-No 106. Available online: https://www.coe.int/en/web/ conventions/full-list/-/conventions/rms/0900001680078b0c (accessed on 15 September 2020).

90. Sousa, L.D. Understanding European Cross-border Cooperation: A Framework for Analysis. J. Eur. Integr. 2013, 35, 669-687. [CrossRef]

91. Prokkola, E.-K. Cross-border regionalization, the INTERREG III A initiative, and local cooperation at the Finnish-Swedish border. Environ. Plan. 2011, 43, 1190-1208. [CrossRef]

92. Gabbe, J.; Ramirez, M.G. AEBR and EGTC-A Long Way to Success, in Legal Setup for Cooperation: EGTC and More, Newsletter Interact, AEBR. 2013. Available online: http://www.interact-eu.net/downloads/7685/Newsletter_ INTERACT_Winter_2013_legal_setup_for_cooperation_EGTC_and_more.pdf (accessed on 20 January 2020).

93. Morata, F. Euroregions and European integration. Doc. Anal. Geogràfica 2010, 56, 41-56.

94. Terlouw, K. Border surfers and Euroregions: Unplanned cross-border behaviour and planned territorial structures of cross-border governance. Plan. Pract. Res. 2012, 27, 351-366. [CrossRef] 
95. Euroregion Beskidy. Available online: http://www.euroregion-beskidy.pl/euroregion-beskidy-2/oeuroregionie/ (accessed on 20 January 2020).

96. Strategia Rozwoju Euroregionu Beskidy na Lata 2016-2023. Maj 2016. Available online: http: //www.euroregion-beskidy.pl/mikroprojekty/interreg-pl-cz/strategia-rozwoju-euroregionu-beskidy-2016-2023/ (accessed on 20 January 2020).

97. Howaniec, H. Rola Klastrów w Rozwoju Lokalnym na Przykładzie Klastra Energetycznego i Klastra Euroregion Beskidy. Studia Mater. Misc. Oeconomicae 2013, 1, 49-67.

98. Komisja Europejska, Pokonywanie Przeszkód w Regionach Przygranicznych. Podsumowanie Wyników Internetowych Konsultacji Społecznych. 21 Września-21 Grudnia 2015 r.; Dyrekcja Generalna ds. Polityki Regionalnej i Miejskiej, Luxembourg. April 2016. Available online: https://ec.europa.eu/regional_policy/ sources/consultation/overcoming-obstacles-border-regions/results/overcoming_obstacles_pl.pdf (accessed on 6 May 2019).

99. Wróblewski, Ł.; Dziadzia, B.; Dacko-Pikiewicz, Z. Sustainable management of the offer of cultural institutions in the cross-border market for cultural services-barriers and conditions. Sustainability 2018, 10, 3253. [CrossRef]

100. Dołzbłasz, S.; Raczyk, A. The role of the integrating factor in the shaping of transborder co-operation: The case of Poland. Quaest. Geogr. 2010, 29, 65-73. [CrossRef]

101. Dołzbłasz, S. Cross-Border Co-Operation in the Euroregions at the Polish-Czech and Polish-Slovak Borders. Eur. Ctries. 2013, 5, 102-114. [CrossRef]

102. Ranking Polskich Miast Zrównoważonych, Arcadis: Poland. 2017. Available online: https://www.arcadis.com/media/6/0/D/\%7B60DA8546-A735-430A-BF9A-6114B0362FD7\%7DRanking\% 20Polskich\%20Miast\%20Zrownowazonych\%20Arcadis\%20FINAL.pdf (accessed on 20 January 2020).

103. Wałachowski, K.; Uciekające Metropolie. Ranking 100 Polskich Miast; Klub Jagielloński: Kraków. 2019. Available online: https://klubjagiellonski.pl/wp-content/uploads/2019/12/uciekajace-metropolie.pdf (accessed on 20 January 2020).

104. Morata, F.; Noferini, A. The Pyrenees-Mediterranean Euroregion: Functional networks, actor perceptions and expectations. In Europe's Changing Geography: The Impact of Inter-Regional Networks; Bellini, N., Hilpert, U., Eds.; Routledge: London, UK, 2013; pp. 171-190. 